Linda Fälth

Institutionen för pedagogik

Linnéuniversitetet

Stefan Gustafson

Institutionen för beteendevetenskap och lärande

Linköpings universitet

Idor Svensson

Institutionen för psykologi

Linnéuniversitetet

Tomas Tjus

Psykologiska institutionen

Göteborgs universitet

\title{
Lärarnas erfarenheter av deltagande i en datorbaserad interventionsstudie som syftar till att öka elevernas läsförmåga
}

\section{Sammandrag}

Flertalet studier har utforskat olika metoder med avsikt att utveckla skriftspråklig förmåga hos elever med läs- och skrivsvårigheter. Trots det är det få, om ens några, studier som har undersökt hur medverkande lärare upplevt sitt deltagande och vilka erfarenheter de gjort av att vara med i dessa studier. I en tidigare studie (Fälth, Gustafson, Tjus, Heimann, \& Svensson, 2013; Gustafson, Fälth, Svensson, Tjus \& Heimann, 2011) visade resultaten att de elever som under en interventionsperiod fick en kombination av datorbaserad fonologisk respektive ortografisk träning gjorde större framsteg på tester som mäter ordavkodning, fonologisk förmåga och läsförståelse än jämförelsegrupperna. Syftet med föreliggande studie är att utifrån ett lärarperspektiv utforska upplevelser och erfarenheter av att delta i ovan nämnda interventionsstudie och att belysa de kvantitativa resultat som finns rapporterade från studien. Arton lärare har intervjuats i denna studie. Resultaten visar att den fasta yttre struktur som interventionen erbjöd samt den flexibilitet som fanns inom respektive intervention upplevdes som positivt och som en bidragande faktor för de här elevernas läsframgångar. Resultaten visade också att kombinationsträningen gynnade både elevernas och lärarnas motivation till interventionen. Slutsatsen är att en datorbaserad lästräningsintervention med fasta ramar men med visst individanpassat innehåll kan vara såväl effektiv som motiverande och positivt påverka interventionerna. 


\section{Inledning}

En utmaning för både forskare och praktiserande lärare är att utveckla, sprida och implementera metoder för att hjälpa elever att erhålla en god läsförmåga (Morris et al., 2012; Torgesen, Alexander, Wagner, Rashotte, Voeller, \& Conway, 2001). Longitudinella interventionsundersökningar kan bidra med viktig kunskap. Generellt visar interventionsstudier inom läsfältet att insatser som innehåller träning i fonologisk medvetenhet har positiva effekter på yngre elevers läsförmåga (ex. Ehri, Nunes, Willows, Valeska Schuster, YaghoubZadeh, \& Shanahan, 2001; Elbro \& Petersen, 2004; Torgesen et al., 2001). Det har också visats att effektiva interventioner kombinerar explicit träning i fonologisk medvetenhet med strukturerad läsundervisning (ex. Hatcher, Hulme, \& Ellis, 1994; Wolff, 2011). Resultat från olika interventionsstudier visar också att insatserna bör vara systematiska (Kjeldsen, Niemi, \& Olofsson, 2003) och intensiva (Denton, Fletcher, Anthony, \& Francis, 2006) för att ge bäst effekt. Metaanalyser beskriver att det är bättre att komprimera träningen snarare än att sprida samma träningsmängd över längre tidsperioder (Bus \& van Ijzendoorn, 1999; Ehri et al., 2001).

I traditionella kvantitativa interventionsstudier är det få som tar upp lärarperspektivet vilket denna studie gör. Det finns således flera kvantitativa interventionsstudier som fokuserat på generella effekter av mer eller mindre specifika interventioner kopplade till läs- och skrivförmågan (Torgesen et al., 2001; Wolff, 2011). Sådan forskning kan bidra till viktig kunskap på generell nivå och visa på möjliga pedagogiska insatser riktade till olika grupper av elever. Det ska dock inte glömmas bort att det kan finnas många olika orsaker till att en viss läspedagogisk metod är mer eller mindre effektiv för en enskild elev i en specifik kontext. Kvalitativ forskning kan bidra med förståelse av hur mötet mellan lärare, elever och själva formen och innehållet i interventionen kan leda till (eller motverka) utveckling av elevers läsförmågor. Det finns få studier som fokuserat på lärares upplevelser av att delta i en interventionsstudie och deras tankar om varför en viss intervention varit effektiv eller mindre effektiv. I föreliggande studie är avsikten att synliggöra lärares upplevelser och erfarenheter av att delta i en interventionsstudie med syfte att främja läsutvecklingen hos elever i årskurs två där tre olika interventioner användes, för att bättre kunna förstå de tidigare observerade och rapporterade generella effekterna.

Bakgrunden till denna intervjustudie är att alla lärare som intervjuats har medverkat i en interventionsstudie kallad Comega och för att förtydliga och försöka förstå de kvantitativa resultat som finns publicerade (Fälth et al., 2013; Gustafson et al., 2011) gjordes föreliggande intervjustudie. I Comega-studien deltog totalt 130 elever och 42 lärare. Etthundra elever ingick i försöksgruppen och valdes ut efter att klasslärare och speciallärare identifierat elever i behov av specialpedagogiska insatser i svenska i årskurs 2. Resterande 30 elever var typiska läsare och utgjorde en kontrollgrupp. Eleverna i försöksgruppen 
fördelades slumpmässigt till fyra grupper med 25 elever i varje grupp. Tre av dessa grupper fick olika typer av interventioner under 25 lektionspass fördelade på i genomsnitt fyra lektionspass/vecka. Lärarna i föreliggande studie hade antingen en eller två elever med, och dessa elever återfinns i alla tre interventionsgrupperna. Interventionen Alla lektionspass var en- till- en, dvs. en elev och en lärare.

Två olika datorbaserade lästräningsprogram användes i interventionerna. Första gruppen fick använda ett program, Omega-IS, som är inriktad på ortografisk läsförståelseträning (Heimann, Lundälv, Tjus \& Nelson, 2004), andra gruppen fick använda ett fonologisk inriktat program kallat COMPHOT (Ferreira, Gustafson, \& Rönnberg, 2003) och tredje gruppen fick en kombination av ovanstående båda träningsprogram. Grupp 1 fick alltså träna läsning utifrån ord- och meningsnivå där förståelsen av det lästa är i fokus. Grupp 2 däremot tränades i fonologisk förmåga medan grupp 3 fick både ock. Den fjärde gruppen var en kontrollgrupp som erhöll ordinarie specialundervisning ('treatment as usual'). Alla elever fick samma mängd träning. Alla elever undersöktes med ett testbatteri innehållande olika läs- och skrivtester vid fem olika tillfällen (för detaljerad information se Gustafson et al., 2011). Resultaten från den studien (Fälth et al., 2013; Gustafson et al., 2011) visade att den grupp elever som erhöll kombinationsträning, d.v.s. använde antingen Omega-IS eller COMPHOT varannan gång, uppvisade den största förbättringen av olika läsförmågor. Ett annat positivt och anmärkningsvärt resultat för kombinationsgruppen var att vid en uppföljning efter ett sommarlov, flera månader efter det att interventionen hade avslutats, hade majoriteten av dem (18 av 25 elever) bedömts att inte längre vara i behov av specialundervisning. Dessa bedömningar hade gjorts på deltagande skolor helt oberoende av forskningsprojektet och det positiva resultatet var unikt just för kombinationsgruppen. Fördelningen av elever som avslutat respektive fortfarande fick specialundervisning skiljde sig signifikant mellan kombinationsgruppen och de andra grupperna, där de flesta fortfarande erhöll specialundervisning (Fälth et al., 2013).

Utgångspunkten för den genomförda interventionsstudien som ligger till grund för intervjuerna var att utveckla effektiva lästräningsprogram för eleverna i första hand. De medverkande lärarna hade en aktiv roll i genomförandet av varje intervention och det blir därför intressant att studera hur lärarna uppfattade själva interventionerna men också sitt eget deltagande. En teori som kan hjälpa till att förklara vad som motiverar lärare i sitt pedagogiska arbete är 'selfdetermination theory'(Deci \& Ryan, 1985; Deci \& Ryan, 2008). Enligt denna teori påverkas motivation av tre faktorer: känsla av kompetens, självbestämmande och social meningsfullhet. Samtidigt som autonomi och valfrihet är viktigt (Seligman, 1975) så är det inte alls säkert att välmående ökar ju fler valmöjligheter som finns tillgängliga. Det verkar snarare finnas en risk för 
"choice-overload" om valen blir alltför många (Iyengar \& Lepper, 2000; Schwartz, 2009).

I de publicerade artiklarna från interventionsstudien (Fälth et al., 2013; Gustafson et al., 2011) diskuterades olika möjliga förklaringar till de positiva resultaten av kombinationsträning dock av mer spekulativ art då vi när dessa publicerades inte hade tillgång till några intervjudata. Den kombinerade träningen erbjöd eleverna lite av varje rent innehållsmässigt och det skulle kunna förklara resultaten genom att alla elever hade nytta av någon del av träningen. Formen tillät dessutom viss anpassning av de olika övningarna och i själva valet av övningarna för att undvika att elever tränade på något de redan kunde eller på något som var alldeles för svårt. Notera dock att i jämförelse med kontrollgruppen som erhöll ordinarie specialundervisning (treatment as usual) så var den kombinerade träningen mer styrd mot ett visst innehåll och en viss form (Fälth et al., 2013; Gustafson et al., 2011). I kontrollgruppen hade lärarna möjlighet att ge varje elev precis den läspedagogik de trodde skulle passa bäst varje gång de träffade eleven. Det gör resultatet för interventionsgrupperna, och särskilt för kombinationsgruppen, ännu mer anmärkningsvärt.

Både Comphot och Omega-IS är läspedagogiska datorprogram och datorbaserad undervisning har visat sig vara till nytta för elever med läs-och skrivsvårigheter (Jimenez et al., 2007; Magnan \& Ecalle, 2006; Nicolson, Fawcett, \& Nicolson, 2000; Regtvoort \& van der Leij, 2007). Dessutom visade Wise, Ring, och Olson (2000) att datorbaserad fonologisk träning resulterade i förbättrad ordavkodning hos elever i lägre årskurser. Ett viktigt påpekande här är att det inte är datorn eller metoden i sig som är det viktiga utan det är hur och i vilket sammanhang datorn som metod används (Folkesson \& Swalander, 2007; Sutherland, Armstrong, Barnes, Brawn, Breeze, \& Gall, 2004). Mot bakgrund av att datorn idag intar en självklar plats inom specialundervisningen är det än viktigare än förr att utvärdera under vilka betingelser och för vilka elever använd programvara leder till läs- och skrivutveckling. Datorer kan ge specialundervisningen specifika och värdefulla träningsmöjligheter, men vägledning behövs, dels om verkningsfull programvara, dels om hur träningen bör läggas upp för att ge bäst effekt för den enskilde eleven. Lärarens roll är betydelsefull vid vägledning av studenterna och samtalet mellan lärare och elev om övningarnas syfte och innehåll fyller en viktig funktion (Gibbons, 2006; Moreno, 2006; Torgesen, Wagner, Rashotte, Herron, \& Lindamood, 2010).

Sammanfattningsvis var utgångspunkten för den här studien de tidigare publicerade resultat från Comega-projektet där särskilt positiva resultat erhölls av en kombination av datorbaserad fonologisk träning och datorbaserad träning på ord och meningsnivå. Syftet med denna intervjustudie var att undersöka och belysa lärares upplevelser och erfarenheter av att ha deltagit i denna interventionsstudie för att förtydliga och försöka förklara de kvantitativa resultat som tidigare publicerats (Fälth et al., 2013; Gustafson et al., 2011). 


\section{Metod}

\section{Deltagare}

Arton lärare deltog i denna semistrukturerade intervjustudie (Bryman, 2006). Alla hade tidigare deltagit $i$ en interventionsstudie där totalt 42 lärare och 100 elever med lässvårigheter deltog. Lärarna i denna studie har haft elever från alla tre interventionsgrupperna. Tre av lärarna har dessutom haft två elever med i projektet, eleverna har då ingått i olika interventionsgrupper. Övriga lärare har haft en elev med i interventionen. Ingen lärare har arbetat med samma intervention mer än en gång. Av praktiska och ekonomiska skäl intervjudes de 18 lärare som befann sig inom ett geografiskt närområde från intervjuaren.

\section{Procedur}

Efter interventionen, dvs. när varje elev hade tränat med respektive träningsprogram vid 25 tillfällen genomfördes semistrukturerade intervjuer med lärarna (Bryman, 2006). Intervjuerna genomfördes enskilt och tog i genomsnitt 45 minuter, spelades in och transkriberades av en av författarna (LF). Frågorna fokuserade på lärarnas deltagande och erfarenheter av att ingå i studien. En tematiskt strukturerad intervjuguide användes för att kontrollera att alla avsedda områden täcktes. De fick svara på frågor relaterat till innehållet i den intervention de genomfört: exempelvis "Hur väl tycker du att den aktuella interventionen passade just din elev?" och "I vilken grad upplevde du att din elev förbättrade sin läsning med hjälp av den aktuella interventionen?”. De svarade också på frågor kring upplägget av studien, exempelvis: "Hur upplevde du intensiteten på interventionen?” och "Hur upplevde du de yttre ramarna som du hade att förhålla dig till?”. Variationen och svårighetsgraden inom varje intervention diskuterades liksom intensitet och tidsåtgång. Kategorier av svar som var semantiskt lika varandra återfinns under samma rubrik. Intervjuerna som gjordes var semistrukturerade (Bryman, 2006). Intervjuaren utgick ifrån två teman som skulle beröras: innehållet i interventionerna samt formen eller strukturen på interventionen. Intervjuerna styrdes av en uppsättning frågeställningar som skulle täckas vid vart och ett av tillfällena. Frågorna ställdes inte alltid i samma ordning och intervjuprocessen var flexibel då frågor, utöver dem som fanns i intervjuguiden ställdes när intervjuaren anknöt till något som intervjupersonen sagt. Intervjuerna baserades med andra ord inte på en uppsättning rigida och i förväg bestämda frågor. Intervjuernas öppna natur gav istället möjligheter till en förändringsprocess, där olika tanketrådar som tidigare intervjupersoner berört nu kunde tas upp och presenteras för den aktuella intervjupersonen (Ahrne \& Svensson, 2012; Bryman, 2006). Exempelvis så kom diskussionen kring användandet av datorn upp vid första intervjutillfället och det ledde till att intervjuaren fortsättningsvis frågade kring vilka erfarenheter lärarna gjort av datorns roll i undervisningen om de inte själva tog upp det till diskussion. En tematisk analys gjordes av de transkriberade intervjuerna 
(Bryman, 2006) genom att utsagor klassificerades och sorterades. Utifrån detta bearbetade material identifierades sedan tre övergripande teman. I avsnittet Resultat och analys presenteras dessa tre teman och belyses med ett urval av centrala citat.

\section{Resultat och analys}

Under första temat samlas intervjusvar som rör strukturella aspekter av interventionerna och faktorer såsom ramar, intensitet och 'time on task' blir synliga. Det andra temat i resultatdelen fokuserar de innehållsliga aspekterna och berör faktorer som flexibilitet, individ- och nivåanpassning. Då denna studie bygger på datorbaserade träningsprogram återfinns ett tema kring lärarnas upplevelser och erfarenheter av sitt deltagande i denna interventionsstudie utifrån användandet av datorn i specialundervisningen.

\section{Struktur - vikten av form, fasta ramar och intensitet}

Det första som betonas av lärarna är att den fasta strukturen för interventioner var viktig. Det fanns en yttre ram att förhålla sig till och som skapade arbetsro:

Jag tror att det för mina elever var formen med det intensiva upplägget vilket innebar att vi faktiskt på ett sätt förbundit oss att jobba i en viss, ganska hög, takt som har påverkat resultatet $i$ en positiv riktning. Upplägget var liksom inte förhandlingsbart. (Lärare 1)

Lärarna uttryckte att intensiteten i denna studie resulterade $\mathrm{i}$ att de tränade elevernas fonologiska färdigheter och läsförståelse mer intensivt än vad de skulle göra om de inte hade deltagit i denna studie. 'Time on task', att ägna tid åt det som träningen var tänkt att ägnas åt var det flera lärare som lyfte:

Jag brukar alltid ha inslag av denna typ av träning i vanliga fall men jag har aldrig under mina 25 år som lärare arbetat så här intensivt under en sådan här förhållandevis lång period. I minuter räknat så har den effektiva träningen här blivit stor tack vara strukturen på upplägget. (Lärare 2)

Här blev det legitimt att verkligen grotta ner sig och ägna mycket tid åt exempelvis olika fonologiska övningar, vilket var precis vad min elev behövde. (Lärare 3)

När lärarna tillfrågades hur de skulle kunna dra nytta av att delta i denna interventionsstudie i sitt framtida arbete så meddelade flera av dem att de skulle omorganisera specialundervisningen efter deltagande i studien. De har för avsikt att planera in en mer intensiv undervisning som pågår under en begränsad period för att sedan bryta och utvärdera den period som gått: 
Nästa termin kommer jag att ha ett helt annat upplägg på min specialundervisning. Jag ska organisera utifrån kortare och mer intensiva perioder med specialundervisning för varje elev för att sedan släppa eleven helt under en period och utvärdera om det ska bli aktuellt med ytterligare en period senare. Vidare måste inte varje arbetspass nödvändigtvis pågå en hel timma. Som det är idag är det schemats moduler som i stort sett styr upplägget på undervisningen och det tänker jag försöka ändra på. (Lärare 4)

Citatet ovan speglar det som flera lärare lyfte som en viktig erfarenhet av sitt deltagande i studien, att fortsättningsvis inte per automatik lägga ett fast schema för specialundervisning i augusti utan att strukturera innehållet allt oftare utifrån ett interventionsbaserat upplägg av undervisningen. Det framkommer i intervjuerna att lärarna upplever att både systematiken som Kjeldsen, Niemi \& Olofsson (2003) argumenterar för och intensiteten (Denton, et al., 2006) på specialundervisningen har synliggjorts under denna tid som interventionsstudien har pågått. Att bygga in pauser så att specialundervisningen inte per automatik löper på med samma intensitet en hel termin eller ett helt läsår är något som flera lärare säger att de "fått upp ögonen” för i och med deltagandet i denna studie. I Underwoods studie (2000) framkom att i skolor där träningspassen var 15-20 minuter långa och skedde tre eller flera gånger i veckan uppnåddes bättre läsresultat än i skolor där passen var timslånga en gång i veckan. Det intensiva upplägget medförde också att lärarna lyfte frågan om hur många sådana här interventioner man som lärare orkar hålla i gång samtidigt:

Det ska också erkännas att det var skönt den dagen då vi kunde bocka av sista passet och ta en paus från denna intensiva träning. (Lärare 5)

För mig blev det en aha-upplevesle när jag i slutet av interventionsperioden insåg hur välförtjänt både jag och eleven tyckte det skulle bli med paus. (Lärare 6)

Tydlighet i strukturen medförde att lärarna kände sig trygga. Det uppskattades att formen var fast, att det fanns en tydlig arbetsgång vad gällde hur ofta träningspassen skulle genomföras att förhålla sig till:

För båda mina elever har det så här i efterhand varit positivt med det intensiva upplägget. Som lärare blev jag tvungen att öronmärka de här elevernas tid till arbete med respektive dataprogram. Jag tror också att de datorbaserade träningsprogrammen har varit bra för mina elever men att jag ser att det kanske kan finns annat, liknande innehåll, som också skulle fungerat. (Lärare 7)

Lärarna påpekade att den fasta, förutbestämda strukturen inte bara gynnade dem utan även eleverna. När eleverna förstått upplägget och var med på noterna så 
slappnade de av och ett slags arbetsro uppstod där de inför varje arbetspass visste vad som förväntades av dem och det menar lärarna var en positiv effekt av upplägget på studien:

Arbetesgången var fastlagd och jag kände att jag kunde förlita mig till den och att jag inte behövde uppfinna hjulet på nytt inför varje lektionsplanering. Detta tror jag uppskattades av mina elever också - att veta vad som förväntas av mig på förhand skapar trygghet oavsett om man är lärare eller elev. (Lärare 3)

\section{Flexibilitet - vikten av möjlighet till individ- och nivåanpassning}

Lärarna ansåg att de kunde vara med och påverka innehållet $\mathrm{i}$ interventionen eftersom lektionerna inte var förutbestämda. De hade vissa fasta ramar att hålla sig inom, vad gäller mängden av sessioner, längden på varje lektion samt vilken av de datorbaserade program de skulle använda. Valet av övningar inom respektive program fick de själva bestämma utifrån de behov som fanns hos den elev de skulle jobba med. Detta innebar att någon elev arbetade igenom i stort sett alla övningar som det aktuella programmet innehöll medan andra elever jobbade längre med ett mindre antal övningar.

Att känna av var eleven befinner sig och anpassa övningarna så att de hela tiden utmanade eleven lagom mycket, jmf den proximala utvecklingszonen (Vygotsky 1934/1962), upplevdes som positivt av alla lärarna. Några av dem menade att just denna individuella nivåanpassning var direkt avgörande för elevernas fortsatta lärande. Enligt Damber (2009) ger lärares observationer under interventionerna värdefull information om hur innehållet och upplägget kan modifieras. Läraren behöver se på undervisningen som ett samspel mellan sig och eleven där båda ska vara aktiva i inlärningsprocessen (Gibbons, 2006). En lärare berättade att hon visste om att hennes elev hade stora fonologiska svårigheter och att det varit lyckosamt att just denna elev blivit lottad till att använda det fonologiska programmet. Deltagandet i interventionen ledde till mera 'time on task' för denna elev vilket också enligt läraren resulterade i en säkrare fonologisk förmåga hos denna elev. Detta stämmer överens med tidigare forskning (Johansson, 1992; Olson \& Wise, 1992; Riis, 1991; Torgensen et al., 2001). Läraren understryker också att om hon inte kunnat anpassa övningarna och lägga dem på rätt nivå för just denna elev så trodde hon inte att resultatet hade blivit alls lika bra. Reichenberg (2008) lyfter fram att det är viktigt att lärare försöker överbrygga motståndet till svårare texter så inte eleverna hamnar på sin egen komfortnivå och som läraren ovan uttrycker det "bjuds lite motstånd”. Läraren kan fungera stöttande och tillsammans med läraren kan eleven utmanas och stöttas (scaffolding) att överträffa sin komfortnivå (Wood, Bruner \& Bross, 1976; Vygostky, 1978).

Upplägget av interventionerna tillät viss individanpassning. Lärarna var tvungna att använda det på förhand bestämda programmet till respektive elev 
men inom varje program fanns en frihet att individanpassa övningarna vilket lyftes fram som positivt:

För min ena elev har det varit fullt tillräckligt att vi använt oss av de första modulerna i programmet och stannat där tills han kände sig säker. Det var avgörande för denna killens självkänsla att vi inte raskat på och tagit oss fram för fort utan att jag medvetet kunnat hålla svårighetsgraden på uppgifterna på en nivå som han kände att han klarade av. För min andra elev var det däremot viktigt att jag som lärare såg till att övningarna bjöd motstånd för att hon inte skulle bli blasé och tycka att det var för enkelt. Jag fick då hoppa över flera av de första momenten i respektive program. (Lärare 8)

Att inom respektive program kunna individanpassa innehållet var något som flera lärare påtalade som positivt. Några blev lättade när de förstod att det inte var en lista med övningar som skulle bockas av och genomföras med samtliga deltagare. Målet var att ingen elev skulle arbeta med varken för svåra eller för enkla uppgifter utan lärarens uppgift var att utifrån dennes elevkännedom välja övningar på en adekvat, lagom utmanande nivå:

För en av mina elever tror jag att det var direkt avgörande att lektionsplaneringen inte var fastlagd från början för vi hann i princip bara nosa på vissa övningar medan vi stannade länge och jobbade igenom andra övningar mycket grundligt. Eleven behövde aldrig känna att han jobbade med för svåra övningar. (Lärare 5)

Några övningar, speciellt de som tränade förmågan att kunna rimma, var på en alldeles för låg nivå för en av mina elever och då kändes det bra att jag $i$ förhand kunde välja bort dessa till förmån för mer utmanande övningar till min ena elev. (Lärare 9)

Att kunna göra individanpassningar gällande svårighetsgrad påtalades av många lärare men även vikten av att kunna välja övningar på samma nivå gällande svårighet men som skilde sig åt gällande upplägg upplevdes som viktigt:

Vissa elever kräver ett långsammare arbetstempo medan till exempel andra mår bra av när övningarna är på tid och de triggas i positiv bemärkelse av övningar som innehåller något tävlingsmoment. Här kunde jag botanisera bland övningarna och välja ut dem som jag trodde skulle passa för mina olika elever. (Lärare 10)

Lärare som hade elever som deltog i olika interventionsgrupper beskrev träningen den kombinerade gruppen (de som tränade med programmen varannan gång) som mest motiverande för eleverna men även för dem som lärare. Lärarna menar att variationen som den kombinerade träningen innebar gjorde att de kände sig motiverade genom hela träningsperioden: 
Att få använda båda träningsprogrammen gjorde att min elev kunde hålla ångan uppe, jag tror att han hade tappat lusten för länge sedan om det inte varit för variationen. Det finns säkert poänger med att träna länge på samma sak och nöta in viss kunskap men för denna kille och säkert många med honom gäller det att hålla motivationen i gång för att det hela ska fungera och då är det nödvändigt med viss variation anser jag. Jag är också beredd att skriva under på att även min motivation påverkades positivt av variationen som den kombinerade gruppen fick sig till livs. (Lärare 2)

De lärare som haft elever som deltagit både i kombinationsgruppen samt i någon av de övriga grupperna är övertygade om att just den innehållsliga variationen inneburit att motivationen har bibehållits under hela interventionen. De menar att de inte varit lika tydligt medvetna om vikten av variationen i undervisningen förut och att denna nya insikt varit värdefull för dem även i andra sammanhang:

Speciellt för dessa elever som verkligen behöver träningen har jag blivit varse om vikten att variera träningen, det verkar finnas en mättnadsgrad när man som elev bör fokusera på något nytt för att inte tappa fokus och gnista. Att använda två olika angreppssätt på lästräningen gjorde att även min motivation som lärare kunde bibehållas. (Lärare 8)

Motivation är en viktig faktor när ett barn ska lära sig läsa (Gillon, 2004; Taube, 2007) och elevernas motivation till förelagda uppgifter är ofta i fokus men intervjusvaren visar också på vikten av variation för bibehållandet av lärarens motivation. Just detta stämmer väl överens med "self-determinsation-thery" (Deci \& Ryan, 2008) där självbestämmande är en viktig faktor för motivationen till arbetet. Att själv kunna påverka innehållet i och upplägget av sina arbetsuppgifter är motivationshöjande och detta verkar stämma för lärares arbetssituation. Lärarens motivation till olika arbetssätt och metoder spela en viktig roll trots detta så är det oftast elevernas motivation som blir föremål för studier av olika slag. Moreno (2006) menar att det är viktigt att ha en diskussion med eleven och förklara varför- och hur de olika delarna i träningen hänger ihop i syfte att öka motivationen till träningen. I linje med Moreno (2006) understryker flera av lärarna vikten av att informera och tydliggöra för eleverna vad de olika övningarna innehöll och varför. I det ena träningsprogrammet (Comphot) var innehållet uppdelat med olika rubriknivåer som presenterade övningarnas övergripande syfte och vad eleven skulle träna på under respektive övning. Flera lärare uppgav att denna information uppskattades av eleverna vilket tyder på att den inre strukturen kring innehållet i träningsprogrammen är viktig.

\section{Datorbaserade interventioner blir en ny slags specialundervisning}

Ett generellt resultat är den positiva upplevelsen av att datorn fungerar som en slags 'tredje part'. All undervisning skedde en-till-en (en lärare och en elev) men 
med fokus på datorn. Lärarna förmedlar upplevelsen av att datorn avdramatiserade undervisningen och att det var bra med fokus på skärmen snarare än på eleven:

För mig blev det väldigt tydligt när NN (eleven) mitt under en övning sa att det var ju himla bra att det var på datorn det blev fel för där går det ju så lätt att rätta till. (Lärare 11)

Det framkom också att lärarna efter deltagandet i studien och med en känsla av att eleverna hade förbättrat sin läsförmåga, framledes planerade att utgå från datorbaserad lästräning för vissa elever. Tidigare hade datorn snarare setts som ett komplement till annat, icke datorbaserat lästräningsmaterial inom specialundervisningen:

Framöver tänker jag mig att för vissa av mina elever utgå från datorbaserade träningsprogram när jag planerar specialundervisningen istället för som nu då jag på sin höjd använt dem som lite extra träning eller som belöning för vissa elever. (Lärare 10)

Lärarna upplevde att överblicken på vilka övningar som erbjuds inom respektive program blev tydligare här på grund av att träningen var datorbaserad än vad det hade varit med liknande typ av träning som inte hade varit multimedial. Den omedelbara feed-backen som de datorbaserade programmen erbjöd ansågs enligt lärarna som positiv för eleverna:

Jag tror att det var lika spännande för NN (eleven) som för mig att invänta feed-backen speciellt kring de lite längre, mer komplicerade övningarna som skedde i flera steg. Här blev det ju klang och jubel om det blev rätt hela vägen. (Lärare 6)

Lärarna tog också upp datorns återkoppling när eleven gjorde fel på en uppgift:

En av mina elever sa vid flera tillfällen att det känns helt okej när datorn rättar mig, och då tänker jag att hon menade att det kan vara lättare att ta kritik eller tillrättavisningar från datorn kanske...(Lärare 12)

Datorn kan fungera stöttande och tillsammans med läraren kan eleven utmanas och stöttas (scafolding) att överträffa sin komfortnivå (Vygostky, 1978; Wood, Bruner \& Bross, 1976). Datorn skulle även kunna fungera som ett sätt att skydda elevens självförtroende då det kanske i vissa sammanhang är lättare för en individ att hantera en dators påpekande och tillrättavisningar framför en lärares. Detta skulle kunna vara en bidragande faktor för vissa elever när att behålla en god skolsjälvbild. 


\section{Sammanfattande diskussion}

Resultaten från denna studie belyser de kvantitativa resultat vi fann i Gustafson et al., 2011 och Fälth et al., 2013 där den lästräningsmetod som innebar en kombination av fonologisk träning och ortografisk förståelseträning visade sig vara mest effektiv när det gällde att främja elevernas läsutveckling på både kort och lång sikt. Den kombinerade träningen innebar en variation av datorbaserad ortografisk och fonologisk träning som gjorde att de lärare vars elev/er tränade med båda programmen upplevde träningen som motiverande och inte lika enformig som lärare från de andra båda grupperna uppger. Detta verkar vara i linje med 'self determination theory' för de deltagande lärarna (Deci \& Ryan, 2008).

Att elever med läs- och skrivsvårigheter bör träna sin fonologiska förmåga finns rapporterat i flera olika studier (t.ex. Catts \& Kahmi, 2005; Elbro, 2004; Snowling, 2000). I denna studie visade resultaten på att en kombination av fonologisk och ortografisk träning gjorde att lärarna upplevde att läsningen förbättrades vilket är i linje med de kvantitativa resultat som finns rapporterade från huvudstudien (Gustafson et al., 2011) och som exempelvis Ehri et al. (2001) och Hatcher, Hulme and Ellis (1994) också rapporterat om. Vikten av flexibilitet inom interventionen är ett tydligt resultat i denna studie, vilket här innebär både omväxling och nivåanpassning med även flexibilitet genomatt kunna individanpassa innehållet efter elevens behov vid det aktuella lektionstillfället. Med omväxling menas här att innehållet är så variationsrikt att motivation bibehålls. Det är dock viktigt att poängtera att omväxlingen sker inom de givna ramarna då tryggheten att datorn beter sig likadant genom hela interventionen upplevdes som positivt. Trots den givna yttre strukturen innebar just friheten som lärarna ändå hade att den interna validiteten inte blir lika hög som om alla elever hade haft exakt samma upplägg även inom ramarna. Som motvikt till den interna validitetsproblematiken står de positiva mervärden med den flexibilitet som erbjöds i form av att vi i forskargruppen drog nytta av varje enskild speciallärares kunskap om individen. Varje deltagande elev arbetade med uppgifter inom respektive program som hans/hennes speciallärare valt ut explicit för just den eleven vid just detta arbetstillfälle. Med nivåanpassning menas att innehållet är på en sådan nivå att det utmanar eleven precis där eleven befinner sig i sin läsutveckling just nu (Jmf. Vygotskys proximala utvecklingszon, 1934/1962). Att kunna individanpassa innehållet efter elevens behov innebär att det kanske inte är hela utbudet som interventionen erbjuder som ska arbetas igenom med varje elev. För vissa elever räcker det gott att gå på djupet och istället repetera vissa av övningarna. Medan det för andra elever krävs en annan matchning av innehållet med fler övningar inom ett visst område och att han eller hon hoppar över vissa övningar för att de var för svåra/enkla vid just detta tillfälle. Detta för att motivationen till arbetet ska upprätthållas och att varje individ ska kunna känna framgång i arbetet. Att möta individen där han 
eller hon befinner sig just idag är en utmaning. God kännedom om elevens styrkor och svårigheter borgar för framgångsrika resultat av åtgärder. Detta är naturligtvis lika viktigt i vardagspraktiken som i interventionsstudier.

Deltagarnantalet är begränsat i denna studie. Av huvudstudiens 42 deltagande lärare deltog 18 i denna studie vilket innebär att resultaten skall tolkas med viss försiktighet. Urvalet var heller inte slumpmässigt bland de 42 deltagarna utan baserades på närhetsprincipen. Ytterligare forskning inom området behövs.

\section{Slutsatser och förslag till fortsatt forskning}

Vår studie har bidragit med ny kunskap om hur lärare uppfattar sitt deltagande i en interventionsstudie och möjliga förklaringar till varför en kombinerad träningsmetod var mest effekt för elever som kämpar med sin läsning. Sammanfattningsvis visar resultaten från denna studie att en fast yttre struktur med givna ramar att förhålla sig till är viktig vid planerandet och genomförandet av interventioner inom läs- och skrivområdet. Samtidigt är det av vikt att det inom de givna ramarna finns en flexibilitet som tillåter att läraren anpassar innehållet utifrån elevens förutsättningar och behov. När olika metoder eller träningsprogram används i undervisningen gynnas både elevens och lärarens motivation till arbetet. Alla resultat tolkas utifrån att det är datorbaserade träningsprogram som använts i studien och synen på datorn som en 'tredje part' i en-till-enundervisningen och med dess omedelbara feedback framstod som positiv. Viktiga frågor i den fortsatta forskningen som kan belysas i samverkan mellan forskare och praktiker är vilka insatser som passar för vilka elever under vilka förhållanden.

\section{Referenser:}

Bus, A. G., \& van IJzendoorn, M. H. (1999). Phonological awareness and early reading: A meta- analysis of experimental training studies. Journal of Educational Psychology, 91, 403- 414.

Catts, H. \& Kamhi, A. (red.) (2005). Language and reading disabilities. 2. ed. Boston, Mass. Pearson Education Inc.

Damber, U. (2009). Using inclusion, high demands and high expectations to resist the deficit syndrome: a study of eight grade three classes overachieving in reading. Literacy, 43, 4349.

Deci, E. L., \& Ryan, R. M. (1985). Intrinsic motivation and self-determination in human behavior. New York: Plenum Press.

Deci, E. L., \& Ryan, R. M. (2008). Self-determination theory: A macrotheory of human motivation, development and health. Canadian Psychology, 49(3), 182-185.

Denton, C. A., Fletcher, J. M., Anthony, J. L., \& Francis, D. J. (2006). An evaluation of intensive intervention for students with persistent reading difficulties. Journal of Learning Disabilities, 39, 447-466. 
Ehri, L. C., Nunes, S. R., Willows, D. M., Valeska Schuster, B., Yaghoub-Zadeh, Z., \& Shanahan, T. (2001). P honemic awareness instruction helps children learn to read: Evidence from the National Reading Panel's meta-analysis. Reading Research Quarterly, 36, 250-287.

Elbro, C. (2004). Läsning och läsundervisning. 1. Uppl. Stockholm: Liber Forssell.

Elbro, C., \& Petersen, D. K. (2004). Long term effects of phoneme awareness and letter sound training: An intervention study with children at risk for dyslexia. Journal of Educational Psychology, 96, 660-670.

Ferreira, J., Gustafson, S., \& Rönnberg, J. (2003). COMPHOT: Computerized phonological training. Linkoping, Sweden: Department of behavioral sciences and learning/Swedish institute for disability research, Linkoping University, Sweden.

Folkesson, A-M. \& Swalander, L. (2007). Self-regulated learning through writing on computers: consequences for reading comprehension. Computers in Human Behavior 23(5), 2488-2508.

Fälth, L., Gustafson, S., Tjus, T. Heimann, M., \& Svensson, I. (2013). Computer-assisted interventions targeting reading skills of children with reading disabilities - A longitudinal study. Dyslexia, 19, 37-53.

Gibbons, P. (2006). Bridging discourses in the ESL classroom. Students, teachers and researchers. London: Continuum.

Gillon, G. (2004). Phonological awareness: from research to practice. The Guilford Press. New York.

Gustafson, S., Fälth, L., Svensson, I., Tjus, T., \& Heimann, M. (2011). Effects of Three Interventions on the reading skills of children with reading disabilities in grade 2. Journal of Learning Disabilities, 44, 123-135.

Hatcher, P., Hulme, C., \& Ellis, A. W. (1994). Ameliorating reading failure by integrating the teaching of reading and phonological skills: The phonological linkage hypothesis. Child Development, 65, 41-57.

Heimann, M., Lundälv, M., Tjus, T., \& Nelson, K. (2004). Omega-Interactive sentences, a multimedia software for language exploration and play. Goteborg, Sweden: Topic Data \& Språkbehandling HB.

Iyengar, S. S. \& Lepper, M. (2000) When choice is demotivating: can one desire too much of a good thing? Journal of Personality and Social Psychology, 79, 995-1006.

Jiménez, J. E., Hernández-Valle, M., Ramírez, G., del Rossario Ortiz, M., Rodrigo, M., Estévez, A., et al. (2007). Computer speech-based remediation for reading disabilities: The size of spelling-to-sound unit in a transparent orthography. Spanish Journal of Psychology, 10, 52-67.

Johansson, M-G. (1992). Synpunkter och erfarenheter av datorstöd i läs och skriv. Nordisk Tidsskrift, for Spesialpedagogikk, 2, 108-113.

Kjeldsen, A-C., Niemi, P., \& Olofsson, Å. (2003). Training Phonological Awareness in Kindergarten Level Children: Consistency is more important than Quantity. Åbo: Department of Special Education.

Magnan, A., \& Ecalle, J. (2006). Audiovisual training in children with reading disabilities. Computers \& Education, 46, 407-425.

Moreno, R. (2006). Learning in high-tech and multimedia environments. Current Directions in Psychological Science, 15, 63-67.

Morris, R., Lovett, M., Wolf, M., Sevcik, R., Steinbach, K., Frijters, J., \& Sharpio, M. (2012). Multiple-Component Remediation for Developmental Reading Disabilities: IQ, Socioeconomic Status and Race as Factors in Remedial Outcome. Journal of Learning Disabilities, 45: 99. 
Nicolson, R., Fawcett, A., \& Nicolson, M. (2000). Evaluation of a computer-based reading intervention in infant and junior schools. Journal of Research in Reading, 23, 194-209.

Olson, R., \& Wise, B. (1992). Reading on the computer with orthographic and speech feedback. Reading and Writing: An Interdisciplinary Journal, 4, 107-144.

Regtvoort, A. G. F. M., \& van der Leij, A. (2007). Early intervention with children of dyslexic parents: Effects of computer-based reading instruction at home on literacy acquisition. Learning and Individual Differences, 17, 35-53.

Reichenberg, M. (2008) "But before you said you believed that...” A longitudinal study of text talks in small groups. The Reading Matrix. 8(1), 158-185.

Riis, U. (1991). Skolan och Datorn. Satsningen datorn som pedagogiskt hjälpmedel 19881991. Linköpings universitet, Tema T Rapport 24.

Schwartz, B. (2009). Incentives, choice, education and well-being. Oxford Review of Education , 35, 391-403.

Snowling, M. (2000). Dyslexia. Oxford: Blackwell Publishers Ltd.

Sutherland, R., Armstrong, V., Barnes, S., Brawn, R., Breeze, N. \& Gall, M. (2004). Transforming teaching and learning: embedding ICT into everyday classroom practices. Journal of Computer Assisted learning. 20(6), 413-425.

Taube, K. (2007). Läsinlärning och självförtroende. Psykologiska teorier, empiriska undersökningar och pedagogiska konsekvenser. 4. Uppl. Stockholm: Nordstedts Akademiska förlag.

Torgesen, J. K., Alexander, A. W., Wagner, R. K., Rashotte, C. A., Voeller, K. K. S., \& Conway, T. (2001). Intensive remedial instruction for children with severe reading disabilities: Immediate and long-term outcomes from two instructional approaches. Journal of Learning Disabilities, 34, 33-58.

Torgesen, J. K., Wagner, R. K., Rashotte, C. A., Herron, J., \& Lindamood, P. (2010). Computer-Assisted Instruction to prevent early reading difficulties in students at risk for dyslexia: Outcomes from Two Instructional Approaches. Annals Of Dyslexia, 60(1), 4056.

Underwood, J.D.M. (2000). A comparison of two types of computer support for reading development. Journal of Research in Reading, 23, 136-148.

Vygotsky, L. S. (1962). Thought and language. Cambridge, MA: MIT Press. (Original work published in 1934).

Vygotsky, L.S. (1978). Mind in society: The development of higher psychological processes. Cambridge, MA: Harvard University Press.

Wise, B., Ring, J., \& Olson, R. (2000). Individual differences in gains from computer-assisted remedial reading with more emphasis on phonological analysis or accurate reading in context. Journal of Experimental Child Psychology 77, 197-235.

Wolff, U. (2011). Effects of a randomized reading intervention study: An application of structural equation modelling. Dyslexia, 17: 295-311.

Wood, D., Bruner, J., \& Bross, G. (1973). The rule of tutoring in problem solving. Journal of child psychology and psychiatry, 17, 89-100. 